\title{
Salafism in Azerbaijan
}

\author{
Giorgi Omsarashvili \\ Ivane Javakhishvili Tbilisi State University
}

\begin{abstract}
The article is written with the support of Shota Rustaveli National Science Foundation and is based on the materials obtained in Azerbaijan relating to the spread of Salafism in Azerbaijan, the interviews with A. Shirinov, an associate professor at the faculty of Theology at Baku State University, S. Hasanli, a rector of Baku Islamic University and G. Suleymanov, a leader of Azerbaijan Salafi community, which were recorded during the scientific visit in Azerbaijan.

Keywords: Republic of Azerbaijan, Caucasus, Islamic Fundamentalism, Salafism, Wahhabism, Radical Islamism, Jihadism, Exstremism, Terrorism, Al-Qaeda, ISIL
\end{abstract}

The spread of Salafism so-called Wahhabism and its radical forms in Azerbaijan began after the collapse of the Soviet Union: A number of international Islamic organizations as well as charity foundations (The Society of the Revival of Islamic Heritage, The Muslim World League, Rabiat Al-Alam al-Islami, International Islamic Organization of Survival Al-Igasa, The Organization of the Help and Support of the Muslims of the Caucasus, Al-Haramain, etc. ${ }^{1}$ ) have become active in Azerbaijan, the mentioned organizations were engaged in conducting the propaganda of radical Islam in addition to performing their organizational activities.

A Palestinian pilgrim Abu Umar Salim Al- Ghazzi played an important role in the spread of Salafism in Azerbaijan, who managed to give proselytism the form of organized activity. ${ }^{2}$ His name is connected to attracting sponsors from the Middle East, who supported the construction of so-called Abu Bakr Mosque of Baku, which was attended by thousands of worshippers during Friday prayers. Later, the mosque has become the centre of Salafists residing in Azerbaijan. ${ }^{3}$

In Azerbaijan at the initial stage, the ideas of Wahhabism were rapidly spread among ethnic Lezgins and Dagestanian people related to them, who live in the northern part of the country and are traditional followers of Sunni Islam. It is worth noting that in these regions, separatist attitudes were merged with Islamic ideas and this resulted in the declaration of the idea of creation the Lezgian Islamic State in the border regions of Azerbaijan and Dagestan. ${ }^{4}$

In Azerbaijan, the modern and radical ideologies of Salafism are wide spread. The followers of Modern Salafism do not support military actions. However, they have negative attitude towards Shia Islam, which is worshipped by the majority of Azerbaijan population.

Jihadism in Azerbaijan: Alongside with the Islamic charity organizations, international terrorist organizations (Al-Qaeda, Al-Jihad, Al-Gama'a al-Islamiyya, Muslim Brotherhood) became active in Azerbaijan in 1990s. ${ }^{5}$

Giorgi Omsarashvili, Ph.D. student, Invited lecturer, Faculty of Humanities, Ivane Javakhishvili Tbilisi State University, Georgia; main research fields: Islamic Fundamentalism, Political Islam, Radicalization, Extremism and Terrorism in Caucasus Region/Terrorist and Extremist Groups/Foreign Fighters. 
The fax, which was sent from Baku, was found in the case materials of the attacks conducted on the USA embassies in Dar Salaam and Nairobi. This served as a confirmation of Al-Qaeda activities in Azerbaijan. ${ }^{6}$

In 1999, Azerbaijan special services arrested the members of a radical Salafist group called Jeyshullah (Army of Allah) and their leader Mubariz Aliev who were planning to attack US embassy. ${ }^{7}$

Salafists controlled so called Lezgian Mosque and Abu Bakr in Baku; 14 mosques were considered as Salafist mosques in small and sparsely populated Qobustan district, 20 mosques in Agsu, and 28 in Khachmaz. The total number of 100 mosques was under control of Salafists in $2001 .^{8}$

Azerbaijan Special Services initiated active measures against extremist and terrorist elements in the country. In 2001, under the decree of $\mathrm{H}$. Aliyev, the State Committee on religious affairs was set up. The Committee conducted supervision on current religious processes in the country and limited the financing of religious groups from foreign countries. ${ }^{9}$

In 2000s, local Islamists became active in Azerbaijan and their involvement in Chechen-Russian war became noticeable. Azerbaijan special services were informed that 13 Azerbaijani radicals, who were the parish of Abu-Bakr Mosque in the past, were killed in the mentioned conflict. ${ }^{10}$

In 1999-2001, the number of Chechen refugees who fled to Azerbaijan reached 10,000; the majority of them lived in Baku. A part of their youngsters were followers of Salafism and attended Abu-Bakr Mosque frequently. The government saw them as a threat. In 2000-2001, the oppression and deportation of Chechen refugees began in Azerbaijan. The facts of their arrest and transfer to the Russian Federation also took place. In addition, the activities of Arabic and Islam organizations were prohibited. ${ }^{11}$

The terrorist organization called The Forest Brothers, which was established in Dagestan 2001 became especially active in Quba and Khachmaz regions of Azerbaijan. ${ }^{12}$

In Azerbaijan, 23 international terrorists were detained and transferred to Eastern Arabian States in 2001-2003. ${ }^{13}$

In March 2006, Azerbaijani media reported that one of the prisoners at Guantanamo was an ethnic Azerbaijani by the name of Polad Safarov. He reportedly used to work as Bin Laden's translator and was recruited from the Abu Bakr mosque. ${ }^{14}$

In 2007, Azerbaijan security services prevented the attempt of the terrorist attack on the embassies of the USA and Great Britain, which was planned by Azerbaijan army officer Kamran Asadov who was in alliance with Jihadists and his accessories. ${ }^{15}$

Radical Islamists, living in Azerbaijan, mainly reside in Sumqayit, Shaki, Quba, Balakan, and Zakatala and equaled to no more than 6-7 thousand persons. In 2012, according to data, it was provided by A. Yunosov. ${ }^{16}$

Peaceful Salafi community member Qamet Suleymanov became an imam of Baku Abu BakrSalafist mosque in 1998. He had to lead the Salafi community through quite adverse situation. Q. Suleymanov set himself aside from violent methods, condemned the ideology of the terrorist organisations and their activities. Qamet Suleymanov separated peaceful Salafists from radical Salafists and did not hesitate to expose anti-state activities of Radicals.

Q. Suleymanov named radical Islamists as Kharijites/“Havarish” (Radicals) ${ }^{17}$ and divided them into two proposed categories: Takfir Jamaat (Takfir people) and Jihad Jamaat (Jihadists). He exposed the desire of Sumqayit Radicals to perform Jihad. In 2004, the government closed mosque in Sumqayit, afterwards the government was restricting Kharijites to visit mosques in Ganja, Zaqatala, and Balakan. In the mentioned cities, Radicals went underground. In such situation, Radicals accused Q. Suleymanov of cooperation with the 
government. $^{18}$

Q. Suleymanov believes that the usage of terms "radical" and "Salafi" interchangeably is wrong; from his point of view, a radical is a Muslim who encourages rivalry in the society and appeals to conduct violence. While discussing Salafism, he states that Salafism contradicts Radicalism and misusing this term is connected to the lack of knowledge of Islam. According to Q. Suleymanov, he is a Salafi himself and he contradicts Radicalism and Violence, due to the fact that he became the subject to assault three times, as he has not diverged from the chosen way of peace. ${ }^{19}$ The Forest Brothers kept accusing Q. Suleymanov in betrayal and were planning to assassinate him in 2008. ${ }^{20}$ Since the day of the assault on him in August 2008, the Abu-Bakr mosque is closed by the decision of the Ministry of the Internal affairs of Azerbaijan. ${ }^{21}$ Q. Suleymanov mentioned that approximately 2,000 Kharijites (Radicals) were planning launching of Jihad in Azerbaijan. ${ }^{22}$

Currently, the representatives of Salafi community are forbidden to conduct religious activity and are kept under the constant control of law enforcement bodies. Frequently the members of law enforcement bodies treat them roughly. A. Yunusov indicated in his work in 2012, that approximately 3,000 Salafs were arrested in Azerbaijan in recent years. ${ }^{23}$

In 2012, Q. Suleymanov opposed Said Buryatsky, one of the leaders of the Caucasus Emirate, ${ }^{24}$ when he replied to him by the article published on the Internet regarding the topic of Jihad in the North Caucasus. ${ }^{25}$

Current State: The Syrian Conflict contributed to separation of representatives of peaceful Azerbaijani Salafists and the representatives of radical Salafi movement. The followers of Modern Salafism are against the participation of their compatriots in the conflicts in Middle East, while Radicals support the active participation of Azerbaijanis in Jihad and the part of them fight as members of ISIL and Al-Nusra Front.

In September 2014, the Ministry of Security of Azerbaijan released the information about 26 Jihadists detained in Baku, who were planning to participate in Jihad on the territory of Syria and who were engaged in smuggling of weapons and explosive substances. ${ }^{26}$

The peaceful Salafi community of Azerbaijan believes that the organization similar to the Islamic State and Al-Qaeda conducts permanent propaganda of violence and assures mainly youngsters in performance of Jihad and the importance of fighting for Islamic Caliphate. ${ }^{27}$

In July 2014, Abdulwaheed Khudair, a representative of the Islamic State, declared that the oil supplies of Azerbaijan belonged to the Islamic Caliphate and threatened with conducting armed activities on the territory of Azerbaijan. $^{28}$

Law Enforcement Bodies of Azerbaijan have been taking active measures up to present to detain persons related to the Islamic State. ${ }^{29}$ In 2015, a terrorist attack on a Baku-Istanbul bus was stopped ${ }^{30}$ and an armed terrorist was killed in Khachmaz District according to the official information. ${ }^{31}$

According to the statement of a researcher A. Shirinov Azerbaijan has adopted a special law to ensure the efficient fight against Radicalism, due to which the persons related to the Islamic State are subject to arrest and termination of citizenship. This law serves as a preventive measure for avoidance of future implications. Alongside with the mentioned facts, the awareness of the population is being raised, including conducting public meeting with the participation of experts and clergymen in different regions of Azerbaijan. ${ }^{32}$

In addition, it is worth noting that in order to avoid the threat of radicalism, Azerbaijan students have restrictions relating to their studies at foreign Islamic universities. ${ }^{33}$

Conclusion: The separation of peaceful Salafis (Fundamentalists) and Extremist Jihadists is vital on the official level. 
Despite the effective work of Security Services of Azerbaijan, the innocent peaceful Salafis are inflicted damage in course of a rough fight against Radicalism and terrorism. Salafis have to tolerate with illegal environment; they have to pray in so-called "shadow mosques" (for example, in private houses), ${ }^{34}$ which increases the risks of their radicalizing. It is essential to integrate the members of Salafi Community into the society and to engage them in the life of the state.

The process of modernization and democratization of state institutions, challenges in the field of Human Rights, social-economic inequality and corruptions provide favorable grounds to radical groups to practice proselytism.

A part of clergymen associated with the state in Azerbaijan has no ability to conduct convincing discussions with Salafis on theological level, which contributes to the weakening of traditional movement.

We should agree with a researcher E. Suleymanov, who believes that the ideology of Jihadism poses a potential threat to the security and sovereignty of Azerbaijan, and the implementation of rough so called "Anti-Wahhabist" policy from the part of the government may lead to conversion of Salafism into transnational ideology for Avars, Lezgs, and Tsakhurs, which will result in providing support to them by fighters active in Dagestan. In such case, Baku may face a new territorial conflict with unforeseeable results. ${ }^{35}$

Iran sees strengthening of Radical Salafi groups as a direct threat and in order to maintain the influence and balance will try to support strengthening pro-Iranian Shia Islam groups.

In the case of empowering Radicalism in Azerbaijan, the Russian Federation will try to actively get involved in the internal affairs of Azerbaijan with the motive of protecting its borders and security.

Apart from the interest of European countries, the oil supplies of Azerbaijan are the subject of interest of states of region and Middle East as well as terrorist organization, which increases the changes for making Radicalism movement more active and importing the ideas of Jihad in Azerbaijan.

Radical Islamic groups in Azerbaijan are extremely active at the regions adjacent to Georgia: Balakan and Zaqatala, which contains risks to the national security of Georgia.

The pipelines of regional and global importance located between Azerbaijan and Georgia as well as railway lines may become under the threat and used as a target by Jihadists.

The tight cooperation between Georgian and Azerbaijan is vital to be maintained in order to jointly prevent threats coming from religious extremism and terrorist organizations.

\section{Notes}

1. Arif Yunusov. "Islam v Azerbaijane.” Baku, 2004, 260.

2. Yunusov A. "Islamskaya palitra Azerbaijana.” Baku: “Adilgoli,” 2012, 55.

3. Svante E. Cornell, “Azerbaijan Since Independence.” 2015, 278.

4. Igor Rotar. "Pod zelenum znamenem Islama. Islamskie radicali v Rossii i SNG." Moscow, 2001, 57.

5. Yunusov A. "Islamskaya palitra Azerbaijana." Baku: "Adilgoli,” 2012, 58.

6. U.S. District Court, Southern District of New York, “US vs. Usama Bin Laden' in Politicization of Islam in Azerbaijan.” 2 May 2001, 5440.

7. Anar Valiyev. “The Two Faces of Salafism in Azerbaijan.” December 7, 2007.

$<$ https://jamestown.org/program/the-two-faces-of-salafism-in-azerbaijan/>.

8. Arif Yunusov. "Islam v Azerbaijane." Baku, 2004, 270.

9. "State Enforces Control Over Religious Entities." AssA-Irada, July 23, 2001.

10. G. Mamedzade. "Prihojanam mecheti ‘Abu-Bekr' obeschayut voznagrajdenie?” News. “Ekho.” 25 October 2001.

11. Arif Yunusov. "Azerbaijan v nachale XXI veka: conflictu i potencialnie ugrozy." Baku. 2007, 116. 
12. V. Azerbaijane. "V. Azerbaidjane I Dagestane deistvyut yacheiki religiozno-ekstremistskoi organizacii 'Lesnii bratia.'” $<$ www.kavkaz-uzel.ru/newstext/news/id/942720.html>.

13. Arif Yunusov. "Islam v Azerbaijane." Baku, 2004, 270.

14. Svante E. Cornell. "Politicization of Islam in Azerbaijan." Central Asia-Caucasus Institute and Silk Road Studies Program, 2006, 57.

15. "Obvinyaemue po dely o popitke sovershenia teraktov protiv zarubezhnyh posolstv dali pokazania v side." $<$ https://ru.sputnik.az/incidents/20081224/42647788.html>.

16. Yunusov A. "Islamskaya palitra Azerbaijana.” Baku: “Adilgol,” 2012, 65.

17. (Arabic demonstrators, rebels), i.e., those who betrayed Ali, the representatives of the oldest radical group in the history of Islam.

18. Yunusov A. "Islamskaya palitra Azerbaijana." Baku: "Adilgol,” 2012, 65.

19. Giorgi Omsarashvili's Interview with Qamet Suleymanov, 23.12.2015, Baku.

20. S. Nasibov. "'Lesnii bratia' obvinyaut Gameta Syleimanova v predatelstve. Po ih slovam, iz za nego v tyrmah nahodyatsa okolo 3000 veryushchih.” News. “Zerkalo.” 29 July 2009.

21. “'Sekretniy prikaz' o zakritii mecheti 'Abu-Bakr?’” News. “Zerkalo.” 17 December 2008.

22. A. Rashidogly. "Yavliaetsa li Azerbaijan kyafarskoi stranoi?” News. "Zerkalo.” 28 October 2008.

23. Yunusov A. "Islamskaya palitra Azerbaijana." "Adilgol," 2012, 67.

24. Alexander Tikhomirov — one of the leaders of an organization called Caucasus Emirate and an ideologist of Jihadism in the North Caucasus.

25. "Est li v Chechne Jihad? Oproverzhenie Gameta Syleimanova nekotorym somnieniam." 31.03.2012. $<\mathrm{http}$ //sunna.press/article/est-li-v-chechne-dzhihad-oproverzhenie-gameta-sulejmanova-nekotorym-somnenijam/>.

26. Azerbaijan arrests 26 people accused of joining Islamic State group, other militants in Syria. $<$ http://www.foxnews.com/world/2014/09/23/azerbaijan-arrests-26-people-accused-joining-islamic-state-group-other.html>.

27. Giorgi Omsarashvili’s Interview with Qamet Suleymanov, 23.12.2015, Baku.

28. The impact of ISIL on Azerbaijan. <http://azeridaily.com/analytics/2066>.

29. Vyhodci s Kavkaza v ryadah IGIL. <http://www.kavkaz-uzel.eu/articles/251513/>.

30. "Details of SSS Operation: Terrorist Planned to Blow up Baku-Istanbul Bus." 28.10.2016. $<$ https://report.az/en/incident/details-of-sss-operation-terrorist-planned-to-blow-up-baku-istanbul-bus-exclusive/>.

31. Armed terrorist killed in Azerbaijan. 25 November 2016. <https://en.trend.az/azerbaijan/society/2689760.html>.

32. Giorgi Omsarashvili's Interview with A. Shirinov, a researcher at Baku State University, 23.12.2015, Baku.

33. Giorgi Omsarashvili's Interview with S. Hasanli, a rector of Baku Islamic University, 22.12.2015, Baku.

34. Bogdan Nedea, Shahib Jafarov, and Orhan Mamedov. "Radical Islam in Azerbaijan." Religion and Conflict Radicalization and Violence in the Wider Black Sea Region. Edition: 1, Chapter: 19, Publisher: ISPR 2012, 360.

35. Emil Souleimanov, Maya Ehrmann. "The Rise of Militant Salafism in Azerbaijan and Its Regional Implications." $<$ http://www.mepc.org/rise-militant-salafism-azerbaijan-and-its-regional-implications $>$. 